\title{
Ocena sytuacji finansowej jednostek samorządu terytorialnego w latach 2012-2014 z wykorzystaniem wskaźników na przykładzie gminy Zgierz
}

Assessment of the financial situation of local government in 2012-2014 using the indicators on the example of the borough of Zgierz

Streszczenie. Celem artykułu jest analiza kondycji finansowej gminy Zgierz za pomocą wskaźników do oceny sytuacji finansowej jednostek samorządu terytorialnego $\mathrm{w}$ perspektywie możliwości ubiegania się o dofinansowanie $\mathrm{z}$ Unii Europejskiej. Analiza wskaźnikowa, która jest często wykorzystywana do podejmowania decyzji strategicznych w przedsiębiorstwie, stanowi także punkt wyjścia dla jednostek samorządu terytorialnego w zakresie planowania i wykonywania przyszłych wydatków budżetowych. Weryfikacja sytuacji finansowej i określenie odpowiednich wskaźników jest także istotne z punktu widzenia ubiegania się o środki inwestycyjne z Unii Europejskie. Ocena gminy Zgierz przeprowadzona została za lata 2012-2014 i zawiera analizę wskaźników budżetowych, na mieszkańca oraz dla zobowiązań według tytułów dłużnych. 
Słowa kluczowe: jednostki samorządu terytorialnego, analiza wskaźnikowa, finanse

Abstract. The aim of the article is to analyze the financial situation of borough Zgierz by using indicators to assess the financial situation of local governments in the perspective of the possibility of applying for funding from the European Union. Ratio analysis, which is often used to make strategic decisions in the company, is also the starting point for local government units in the planning and execution of future budget expenditure. Verification of the situation and determining the appropriate financial indicators is also important from the point of view of applying for funds from the European Union. Zgierz The rating was carried out in 2012-2014 and analysis of indicators: the budget, per capita, as well as the titles of debt obligations..

Keywords: local government units, ratio analysis, finance

\section{Wprowadzenie}

Samorząd w Polsce jest obligatoryjnym zrzeszeniem mieszkańców danego terytorium utworzonym dla realizacji zadań o charakterze lokalnym bądź regionalnym w celu zaspokajania potrzeb ludności zamieszkałej na danym terenie w zakresie użyteczności publicznej1. Istotną cechą samorządu terytorialnego jest jego samodzielność, co stanowi zarówno cel jak i skutek decentralizacji². Wyróżnikiem samodzielności samorządów jest prawo do samodzielnego uchwalania budżetu, który predestynuje do prowadzenia gospodarki finansowej. Jako plan finansowy uwzględniający wpływy i wydatki, budżet umożliwia wypełnianie obowiązków wobec społeczności lokalnej. Jako administracja państwowa samorządy nie podlegają hierarchicznie innym jednostkom i są uprawnione do samodzielnego działania $w$

\footnotetext{
${ }^{1}$ Jastrzębska M. Nowy model samorzqdu terytorialnego. Istota, zadania, autonomia, władze, jednostki organizacyjne, finanse, nadzór., Samorząd terytorialny, 1999, nr 1-2, str. 14.

${ }^{2}$ Kosek- Wojnar M. Samodzielność jednostek samorzqdu terytorialnego $w$ sferze wydatków [w:]

Zeszyty naukowe nr 4 Wyższej Szkoły Ekonomicznej w Bochni, 2006, str. 76.
} 
granicach określonych prawem ${ }^{3}$ Sprawne zarządzanie finansami jest warunkiem prawidłowej realizacji celów i zadań przez jednostki samorządu terytorialnego. Od jakości i efektywności wszystkich etapów procesu zarządzania, a więc od planowania, organizowania, przewodzenia i kontroli zależy wynik finansowy jaki osiąga dana jednostka oraz to $\mathrm{w}$ jakim stopniu zaspokaja ona potrzeby ludności lokalnej. Posiadając takie same zasoby i działając $\mathrm{w}$ zbliżonych warunkach ekonomiczno- społecznych można osiągnąc odmienne rezultaty. Innymi słowy przy takiej samej ilości środków finansowych mogą zostać zrealizowane zadania o różnej jakości. Właściwe zarządzanie finansami jednostki samorządu terytorialnego jest zatem kluczowym czynnikiem pozwalającym na jej sprawne funkcjonowanie4. Decyzje podejmowane $\mathrm{w}$ ramach zarządzania jednostką samorządu terytorialnego wpływają na to czy jest ona w stanie terminowo obsługiwać zaciągnięte długi, a także finansować swój dalszy rozwój. Metodą pomocną przy ocenie sytuacji finansowej samorządów jest analiza wskaźnikowa. Stanowi ona także punkt wyjścia dla jednostek samorządu terytorialnego w zakresie planowania i wykonywania przyszłych wydatków budżetowych.

Celem niniejszego artykułu jest zbadanie kondycji finansowej gminy Zgierz za pomocą analizy wskaźnikowej w perspektywie możliwości ubiegania się o dofinansowanie z Unii Europejskiej. Analizy dokonano w oparciu o wskaźniki rekomendowane przez Ministerstwo Finansów do oceny sytuacji finansowej poszczególnych jednostek samorządu terytorialnego za lata 2012- 2014.

\section{Charakterystyka gminy Zgierz}

Gmina jest podstawową jednostką samorządu terytorialnego i realizuje zadania o charakterze lokalnym, które nie są zastrzeżone dla innych podmiotów. Otrzymuje on.a środki konieczne do realizacji

\footnotetext{
${ }^{3}$ Panejko J. Geneza i podstawy samorządu europejskiego, Wilno, 1934, str. 111.

${ }^{4}$ Wyrębek H. Zarzq̨dzanie finansami jednostek samorzqdu terytorialnego na przykładzie gminy [w:] Zeszyty naukowe. Polityki europejskie, zarządzanie i marketing. Nr 4 (53), 2010, str. 143.
} 
celów z budżetu państwa w formie dotacji celowych i w wysokości koniecznej do wykonania zadań5.

Gmina Zgierz jest jedną ze 177 gmin województwa łódzkiego, a wraz z 8 innymi gminami tworzy powiat zgierski. W skład gminy wchodzi 69 miejscowości zorganizowanych w 40 sołectw.

Pod względem powierzchni (ok. 20.000 ha) jedną z największych gmin polskich i największą w województwie łódzkim. Usytuowana jest w północnej części województwa łódzkiego i graniczy bezpośrednio z Łodzią oraz Zgierzem. Taka bliskość sprawia, że jest ona dobrze skomunikowana z tymi miastami poprzez sieć drogową, kolejową oraz linię tramwajową. Korzystne położenie w centrum Polski, zwłaszcza w kontekście docelowego układu dróg krajowych i autostrad, zwiększa znacznie dostępność Gminy Zgierz zarówno w układzie krajowym, jak i międzynarodowym6.

W dniu 1 stycznia 2012 roku liczba ludności Gminy Zgierz wynosiła 12142 stałych mieszkańców, natomiast na koniec roku 2014 zameldowanych tu było już ponad 13 tysięcy mieszkańców. Od wielu lat zauważalny jest wzrost liczby ludności spowodowany przesiedleniami, przeważnie z terenów aglomeracji łódzkiej.

Gmina Zgierz jest gminą wiejską o charakterze rolniczym i rekreacyjnym. Na jej terenach dominują grunty o słabej bonitacji gleby. Nie występują grunty orne I i II klasy, natomiast przeważają grunty klasy V. Niekorzystną cechą rolnictwa gminy jest niewielka powierzchnia poszczególnych gospodarstw rolnych.

Gmina należy do największych i najbardziej zalesionych gmin województwa łódzkiego. Powierzchnia zalesienia w Gminie Zgierz plasuje ją na czołowym miejscu pod względem powierzchni zalesio-

\footnotetext{
${ }_{5}^{5}$ Jastrzębska M. Finanse jednostek samorządu terytorialnego, Wolters Kluwer Polska, Warszawa, 2012, s. 27.

${ }^{6}$ Strategia rozwoju gminy Zgierz na lata 2015-2020, Zgierz, 2015.
} 
nych w powiecie zgierskim. Obszar Gminy Zgierz w 80\% stanowi obszar chronionego krajobrazu

Gmina znajduje się na obszarze działania Łódzkiej Specjalnej Strefy Ekonomicznej (podstrefa w Lućmierzu o pow. ok. 11,5 ha), a najbliższe podstrefy to: Ozorków (7 km), Zgierz (8,5 km), Aleksandrów Łódzki i Łęczyca (po 20 km), Konstantynów Łódzki (22km) oraz Łódź i Stryków (po 23 km).

Złoża surowcowe występujące na obszarze Gminy Zgierz to przede wszystkim cechsztyński wysad solny oraz pokłady węgla brunatnego okolic Rogóźna?7.

\section{Ocena sytuacji finansowej gminy}

Budżet gminy jest narzędziem zapewniającym jej samodzielność w działaniu i finansowaniu. Prawidłowe zarządzanie finansami daje możliwość wywiązywania się z celów i zadań nałożonych na gminę. W ramach oceny sytuacji finansowej gminy analizie poddano strukturę dochodów i wydatków w latach 2012-2014. W strukturze dochodów i wydatków wyróżniono dochody i wydatki bieżące i majątkowe. Wyszczególniono także dochody własne stanowiące różnicę pomiędzy dochodami ogółem a otrzymanymi dotacjami i subwencją ogólną.

Tabela 1. Struktura dochodów gminy Zgierz w latach 2012-2014

\begin{tabular}{|l|r|r|r|}
\hline & \multicolumn{1}{|l|}{2012} & \multicolumn{1}{l|}{2013} & \multicolumn{1}{l|}{2014} \\
\hline $\begin{array}{l}\text { Dochody bie- } \\
\text { żące }\end{array}$ & $31632671 \mathrm{zl}$ & $34079187 \mathrm{zl}$ & $38736359 \mathrm{zl}$ \\
\hline $\begin{array}{l}\text { Dochody ma- } \\
\text { jątkowe }\end{array}$ & $876256 \mathrm{zl}$ & $721301 \mathrm{zl}$ & $998280 \mathrm{zl}$ \\
\hline
\end{tabular}

${ }^{7}$ Raport o stanie gminy Zgierz, Zgierz, 2013. 


\begin{tabular}{|lc|r|r|r|}
\hline $\begin{array}{l}\text { Dochody wła- } \\
\text { sne }\end{array}$ & $28306343 \mathrm{zl}$ & $29995592 \mathrm{zl}$ & $34570834 \mathrm{zl}$ \\
\hline $\begin{array}{l}\text { Dochody ra- } \\
\text { zem }\end{array}$ & $32508927 \mathrm{zł}$ & $34800488 \mathrm{zl}$ & $39734636 \mathrm{zl}$ \\
\hline
\end{tabular}

Źródło: Opracowanie własne na podstawie sprawozdań z wykonania budżetu za lata 2012-2014 oraz Strategii rozwoju gminy Zgierz na lata 2015-2020

Dochody w gminie Zgierz w badanym okresie wzrosły o 7225709 zł, co stanowiło $22,9 \%$.

Dochody bieżące rosły $\mathrm{w}$ każdym roku badanego okresu. W 2013 r. był to wzrost o 7,7\% w stosunku do roku poprzedniego, natomiast w 2014 odnotowano o 13,7\% większy dochód bieżący w porównaniu z rokiem ubiegłym. Główne źródła dochodów bieżących gminy $\mathrm{w}$ badanym okresie to: dochody z podatków i opłat, udział $\mathrm{w}$ podatkach państwowych oraz subwencja oświatowa. Natomiast dochody majątkowe spadły w roku 2013, by następnie ulec znacznemu ( ponad 38\%) wzrostowi w 2014r.

Dochody własne pojmowane jako dochody ogółem pomniejszone o subwencje i dotacje również wykazują tendencję wzrostową. Taki stan rzeczy może świadczyć o budowaniu coraz większej niezależności gminy od środków z budżetu państwa.

Tabela 2. Struktura wydatków gminy Zgierz w latach 2012-2014

\begin{tabular}{|l|c|c|c|}
\hline & 2012 & 2013 & 2014 \\
\hline $\begin{array}{l}\text { Wydatki mająt- } \\
\text { kowe }\end{array}$ & $3078557 \mathrm{zł}$ & $2471407 \mathrm{zł}$ & $5364342 \mathrm{zł}$ \\
\hline $\begin{array}{l}\text { Wydatki bieżą- } \\
\text { ce }\end{array}$ & $28761890 \mathrm{zl}$ & $30111555 \mathrm{zl}$ & $32817976 \mathrm{zł}$ \\
\hline
\end{tabular}




\begin{tabular}{|l|l|l|l|}
\hline Wydatki razem & $31840447 \mathrm{zl}$ & $32582962 \mathrm{zl}$ & $38182318 \mathrm{zl}$ \\
\hline
\end{tabular}

Źródło: Opracowanie własne na podstawie sprawozdań z wykonania budżetu za lata 2012-2014 oraz Strategii rozwoju gminy Zgierz na lata 2015-2020.

Wykonane wydatki ogółem $\mathrm{w}$ badanym okresie wykazują tendencję rosnącą. W roku 2013 stało się to głównie na skutek zwiększenia wydatków bieżących. W roku kolejnym wystąpił wzrost zarówno wydatków bieżących jak i materialnych. Analiza wydatków wskazuje, że gmina przeznaczała środki głównie na zadania bieżące, doraźne ograniczając przy tym wydatki inwestycyjne. Największe wydatki ponoszone były na oświatę i wychowanie, gospodarkę komunalną i ochronę środowiska oraz opiekę społeczną.

Tabela 3. Wyniki finansowe gminy Zgierz w latach 2012-2014

\begin{tabular}{|l|r|r|r|}
\hline & \multicolumn{1}{|l|}{2012} & \multicolumn{1}{|l|}{2013} & 2014 \\
\hline $\begin{array}{l}\text { Dochody ogó- } \\
\text { łem }\end{array}$ & $32508927 \mathrm{zl}$ & $34800488 \mathrm{zl}$ & $39734636 \mathrm{zl}$ \\
\hline $\begin{array}{l}\text { Wydatki ogó- } \\
\text { łem }\end{array}$ & $31840447 \mathrm{zl}$ & $32582962 \mathrm{zl}$ & $38182318 \mathrm{zl}$ \\
\hline $\begin{array}{l}\text { Wynik finan- } \\
\text { sowy }\end{array}$ & $668480 \mathrm{zl}$ & $2217526 \mathrm{zl}$ & $1552318 \mathrm{zl}$ \\
\hline
\end{tabular}

Źródło: Opracowanie własne na podstawie sprawozdań z wykonania budżetu za lata 2012-2014 oraz Strategii rozwoju gminy Zgierz na lata 2015-2020.

Określenie relacji pomiędzy dochodami i wydatkami oddaje efekt podejmowanych w ramach samorządów decyzji. Jednocześnie jest skutkiem realizowanych działań na rzecz społeczeństwa lokalnego. ${ }^{8} \mathrm{~W}$ badanym okresie gmina Zgierz osiągała dodatni wynik finan-

\footnotetext{
8 Mioduchowska- Jaroszewicz Edyta, Metody i kierunki oceny kondycji finansowej jednostek samorzq̨du terytorialnego, Zeszyty naukowe Uniwersytetu Szczecińskiego nr 786, Finanse, Rynki Finansowe, Ubezpieczenia nr 64/2, 2013, str. 134.
} 
sowy, czyli nadwyżkę budżetową. Największą nadwyżkę zanotowano w roku 2013 i wynosiła ona 2217526 zł. Nadwyżka budżetowa w gminie może pojawić się w skutek pozyskania dodatkowych źródeł dochodu, oszczędności w wydatkowaniu środków lub niezrealizowaniu zaplanowanych działań9.

\section{Analiza wskaźnikowa}

Samorząd ma możliwość samodzielnego podejmowania decyzji związanymi z pozyskiwaniem środków na swoją działalność oraz ich wydatkowaniem. Efektem tych decyzji jest wielkość ponoszonych wydatków i wygenerowanych dochodów oraz stopień i zakres realizacji zadań przez jednostki. Do prawidłowego i efektywnego zarządzania finansami niezbędna jest informacja jaki wpływ na sytuację finansową w jakiej znajduje się samorząd terytorialny mają poszczególne czynniki. Związki i zależności pomiędzy różnymi składnikami sprawozdania finansowego są badane za pomocą wskaźników.

Analiza wskaźnikowa jest składową analizy finansowej stanowiąca uzupełnienie badania podstawowych dokumentów finansowych ${ }^{10}$. W ramach tego badania tworzy się szereg wskaźników będących relacją poszczególnych pozycji sprawozdania finansowego i pomagających ocenić działalność danej jednostki. Analiza dostarcza informacji na temat sytuacji finansowej w gminie, a także wspomaga proces planowania budżetowego i rozwój inwestycji11.

Do oceny sytuacji finansowej jednostek samorządu terytorialnego wykorzystywany jest zestaw powiązanych ze sobą logicznie wskaźników. Ministerstwo Finansów przygotowuje cyklicznie wskaźniki dla jednostek samorządu terytorialnego, mogących stanowić

\footnotetext{
${ }^{9}$ Kosek-Wojnar M. Surówka K., Finanse samorządu terytorialnego, Kraków 2002, s. 83-85.

10 Łukomska- Szarek J. Analiza wskaźnikowa w procesie zarzq̨dzania finansami samorządów [w:] Studaii Materiały. Miscellanea Oeconomicae, Zarządzanie i finanse nr 2/2012, Kielce, 2012, str. 274.

11 Łukomska- Szarek J. Wskaźnikowa ocena działalności inwestycyjnej samorząów terytorialnych. [w:] Zeszyty Naukowe Uniwersytetu Szczecińskiego „Finanse, Rynki Finansowe, Ubezpieczenia" nr 26, 2010, str. 573.
} 
podstawę do określania możliwości kredytowych jednostek oraz do podejmowania decyzji związanych z ich rozwojem ${ }^{12}$. Są one zdefiniowane w grupach wskaźników budżetowych, na mieszkańca oraz dla zobowiązań według tytułów dłużnych.

Najbardziej przydatną grupą są wskaźniki budżetowe. Dotyczą one struktury dochodów i wydatków a także relacji pomiędzy dochodem a nadwyżką operacyjną. Odnoszą się także do samofinansowania jednostki13.

Tabela 4. Zestawienie wskaźników budżetowych dla gminy Zgierz

\begin{tabular}{|c|c|c|c|c|c|c|c|}
\hline & & \multicolumn{2}{|c|}{2012} & \multicolumn{2}{|c|}{2013} & \multicolumn{2}{|c|}{2014} \\
\hline L.P. & Nazwa wskaźnika & $\begin{array}{l}\text { Gmina } \\
\text { Zgierz }\end{array}$ & $\begin{array}{l}\text { Srednia } \\
\text { dla gmin } \\
\text { wiejskich }\end{array}$ & $\begin{array}{l}\text { Gmina } \\
\text { Zgierz }\end{array}$ & $\begin{array}{l}\text { Srednia } \\
\text { dla gmin } \\
\text { wiejskich }\end{array}$ & $\begin{array}{l}\text { Gmina } \\
\text { Zgierz }\end{array}$ & $\begin{array}{l}\text { Srednia } \\
\text { dla gmin } \\
\text { wiejskich }\end{array}$ \\
\hline B1 & $\begin{array}{l}\text { Udzial dochodów } \\
\text { biezacych w dochodach } \\
\text { ogólem }\end{array}$ & $97,3 \%$ & $90,3 \%$ & $97,9 \%$ & $92,2 \%$ & $97,5 \%$ & $92,0 \%$ \\
\hline B2 & $\begin{array}{l}\text { Udzial dochodow } \\
\text { wlasnych w dochodach } \\
\text { ogólem }\end{array}$ & $50,8 \%$ & $35,2 \%$ & $53,4 \%$ & $36,8 \%$ & $55,4 \%$ & $38,5 \%$ \\
\hline B3 & $\begin{array}{l}\text { Udzial nadwyżki } \\
\text { operacyjnej dochodach } \\
\text { ogólem }\end{array}$ & $8,8 \%$ & $8,6 \%$ & $11,4 \%$ & $9,8 \%$ & $14,9 \%$ & $9,4 \%$ \\
\hline B4 & $\begin{array}{l}\text { Udzial wydatków } \\
\text { majątkowych w } \\
\text { wydatkach ogólem }\end{array}$ & $9,7 \%$ & $17,2 \%$ & $7,6 \%$ & $16,3 \%$ & $14,0 \%$ & $18,1 \%$ \\
\hline B5 & $\begin{array}{l}\text { Obciążenie wydatków } \\
\text { biezacych wydatkami na } \\
\text { wynagrodzenia i } \\
\text { pochodne od } \\
\text { wynagrodzeń }\end{array}$ & $49,3 \%$ & $48,6 \%$ & $48,8 \%$ & $48,2 \%$ & $47,3 \%$ & $47,3 \%$ \\
\hline B6 & $\begin{array}{l}\text { Udzial nadwyżki } \\
\text { operacyjnej i dochodów } \\
\text { ze sprzedaży majątku w } \\
\text { dochodach ogólem }\end{array}$ & $9,5 \%$ & $9,5 \%$ & $12,5 \%$ & $10,8 \%$ & $15,4 \%$ & $10,3 \%$ \\
\hline B7 & $\begin{array}{l}\text { Wskaźnik } \\
\text { samofinansowania }\end{array}$ & $121,7 \%$ & $153,0 \%$ & $189,7 \%$ & $162,9 \%$ & $128,9 \%$ & $112,6 \%$ \\
\hline
\end{tabular}

Źródło: Opracowanie własne na podstawie danych Ministerstwa Finansów

\footnotetext{
12 Wskaźniki do oceny sytuacji finansowej jednostek samorządu terytorialnego w latach 20122014, Ministerstwo Finansów, Warszawa, 2015, str. 2.

13 Będzieszak M. Кoтu potrzebne sq wskaźniki?, Gospodarka i finanse, 2012, dostęp http://www.wspolnota.org.pl/index.php?id=9\&tx_news_pi1\%5Bcontroller\%5D=News\&tx_new s_pi 1\%5Baction\%5D=detail\&tx_news_pi1\%5Bnews\%5D=25176\&cHash=596978ee684be84f2e 05224bcad545b3 z dnia 07.05.2016r.
} 
Wskaźnik B1 uwidacznia jaką część dochodów ogółem stanowią dochody bieżące. Poprzez dochody bieżące rozumiane są te, które nie są dochodami majątkowymi, a więc nie są przeznaczone na inwestycje, nie pochodzą ze sprzedaży majątku ani z tytułu przekształcenia prawa użytkowania wieczystego w prawo własności. Wartość wskaźnika dla gminy Zgierz jest wysoka w całym badanym okresie i jednocześnie wyższa od średniej wartości wskaźnika dla wszystkich gmin, co może świadczyć o dobrej sytuacji finansowej.

Wskaźnik B2 mówi o stosunku dochodów ogółem do dochodów własnych. Dochody własne są tu rozumiane jako dochody ogółem pomniejszone o subwencję ogólną i dotacje. Wartość wskaźnika dla gminy Zgierz jest znacznie wyższa od średnio dla wszystkich gmin wiejskich. Ponadto tendencja wzrostowa wskaźnika pokazuje, iż gmina w coraz większym stopniu uniezależnia się od dochodów z budżetu państwa.

Kolejny wskaźnik B3 odnosi się do nadwyżki operacyjnej, traktowanej jako różnice pomiędzy dochodami bieżącymi i wydatkami bieżącymi. Informuje on jaką część dochodu ogółem stanowi nadwyżka, będąca dodatnim wynikiem bieżącym. Wynik budżetu finansowego bardzo wiele mówi o kondycji finansowej gminy. Jeśli jednostka osiągnie nadwyżkę operacyjną oznacza to, że ma ona możliwości inwestycyjne, rozwojowe, posiada środki na obsługę i spłatę zadłużenia. Deficyt finansowy natomiast świadczy o tym, że wydatki są wyższe od dochodów, zatem zadania jednostki są wykonywane kosztem sprzedaży majątku lub na skutek powiększania długu. Gmina Zgierz w całym badanym okresie osiągała dodatni wynik bieżący. Wartość wskaźnika dla gminy Zgierz charakteryzuje się tendencją rosnącą i jest jednocześnie większa od średniej wartości wskaźnika dla wszystkich gmin wiejskich. Świadczy to o dobrej sytuacji finansowej gminy. Badana jednostka od 2012 r. zwiększa swoje zdolności inwestycyjne i ma możliwość zwiększania wydatków bieżących.

Wskaźnik B4 udziału wydatków majątkowych w wydatkach ogółem był niższy dla gminy Zgierz niż średnio dla innych gmin wiej- 
skich. Oznacza to, że badana jednostka mniej niż inne gminy inwestowała w danym okresie. Wskaźnik osiągną najwyższą wartość w roku 2014 i wtedy wydatki majątkowe były największe.

Wskaźnik B5 wskazuje jaką część wydatków bieżących stanowią wydatki na wynagrodzenia i pochodne od wynagrodzeń. Wskaźnik ten nie wykazuje dużych wahań i nie odbiega od średniej wartości wskaźnika dla innych gmin. W latach 2012- 2014 wyniósł on odpowiednio: 49,3\%, 48,8\% oraz 47,3\%.

Wskaźnik B6 stanowi uszczegółowienie informacji, które daje wskaźnik B3. Wskazuje on na jaki udział w dochodzie ogółem ma nadwyżka operacyjna wraz z dochodami ze sprzedaży majątku. Podobnie jak w przypadku wskaźnika B3 gmina Zgierz osiąga dodatnią wartość wskaźnika B6 i jest ona większa od średniej dla innych gmin wiejskich.

Wskaźnik B7 daje odpowiedź na pytanie w jakim stopniu jednostka jest $\mathrm{w}$ stanie finansować inwestycje środkami własnymi. W przypadku gminy Zgierz wskaźnik ten osiąga wysokie wartości co świadczy o małym ryzykiem utraty płynności finansowej w związku $\mathrm{z}$ obsługą zadłużenia. Oznacza to także, że gmina ma niewykorzystane możliwości inwestycyjne.

Kolejną grupą wskaźników zaproponowanych przez Ministerstwo Finansów są wskaźniki „na mieszkańca”

Tabela 5. Zestawienie wskaźników na mieszkańca dla gminy Zgierz

\begin{tabular}{|c|c|c|c|c|c|c|c|}
\hline & & \multicolumn{2}{|c|}{2012} & \multicolumn{2}{|c|}{2013} & \multicolumn{2}{|c|}{2014} \\
\hline L.P. & Nazwa wskaźnika & $\begin{array}{l}\text { Gmina } \\
\text { Zgierz }\end{array}$ & $\begin{array}{l}\text { Srednia } \\
\text { dla gmin } \\
\text { wiejskich }\end{array}$ & $\begin{array}{l}\text { Gmina } \\
\text { Zgierz }\end{array}$ & $\begin{array}{l}\text { Srednia } \\
\text { dla gmin } \\
\text { wiejskich }\end{array}$ & $\begin{array}{l}\text { Gmina } \\
\text { Zgierz }\end{array}$ & $\begin{array}{l}\text { Srednia } \\
\text { dla gmin } \\
\text { wiejskich }\end{array}$ \\
\hline L1 & $\begin{array}{l}\text { Transfery bieżące na } \\
\text { mieszkańca }\end{array}$ & $1187,51 \mathrm{zl}$ & $\begin{array}{r}1822,30 \\
\mathrm{zl}\end{array}$ & $\begin{array}{r}1207,88 \\
\mathrm{zl}\end{array}$ & $\begin{array}{r}1845,40 \\
\mathrm{zl}\end{array}$ & $\begin{array}{r}1269,88 \\
\mathrm{zl}\end{array}$ & $\begin{array}{r}1865,77 \\
\mathrm{zl} \\
\end{array}$ \\
\hline L2 & $\begin{array}{l}\text { Nadwyżka operacyjna } \\
\text { na mieszkańca }\end{array}$ & $222,32 \mathrm{zl}$ & $292,90 \mathrm{zl}$ & $\begin{array}{r}301,38 \\
\mathrm{zl} \\
\end{array}$ & $334,40 \mathrm{zl}$ & $\begin{array}{r}444,52 \\
\mathrm{zl} \\
\end{array}$ & $338,94 \mathrm{zl}$ \\
\hline L3 & $\begin{array}{l}\text { Zobowiązania ogólem } \\
\text { na mieszkańca }\end{array}$ & $986,72 \mathrm{zl}$ & $926,30 \mathrm{zl}$ & $\begin{array}{r}845,21 \\
\mathrm{zl} \\
\end{array}$ & $926,00 \mathrm{zl}$ & $\begin{array}{c}693,28 \\
\mathrm{zl}\end{array}$ & $963,66 \mathrm{zl}$ \\
\hline
\end{tabular}

Źródło: Opracowanie własne na podstawie danych Ministerstwa Finansów. 
Wskaźnik L1 określa stosunek transferów bieżących rozumianych jako sumę subwencji ogólnej i dotacji bieżącej do liczby mieszkańców jednostki samorządu terytorialnego. W gminie Zgierz w latach 20122014 wskaźnik ten wynosił odpowiednio 1187,51, 1207,88, 1269,88. Poziom wskaźnika był niższy niż średni dla gmin wiejskich.

Wskaźnik L2 informuje ile środków wypracowanych w nadwyżce operacyjnej przypada na jednego mieszkańca. W badanej jednostce wskaźnik ten ma wyraźną tendencję rosnącą. W roku 2014 wyniósł 444,52 zł i był wyższy niż średnia nadwyżki operacyjnej na mieszkańca w innych gminach.

Kolejny wskaźnik daje informacje ile zobowiązań według tytułów dłużnych przypada na jednego mieszkańca. W tym przypadku dla gminy Zgierz ma on wyraźną tendencję malejącą, co oznacza, że zadłużenie gminy jest coraz mniejsze, a także że zmniejszają się nakłady inwestycyjne ponoszone przez gminę. W 2013 i 2014 r. wskaźnik dla badanej jednostki był znacznie niższy niż średnio dla innych gmin wiejskich.

Trzecią grupą wskaźników do oceny sytuacji finansowej jednostek samorządu terytorialnego są wskaźniki dla zobowiązań według tytułów dłużnych.

Tabela 6. Zestawienie wskaźników dla zobowiązań według tytułów dłużnych dla gminy Zgierz

\begin{tabular}{|c|c|c|c|c|c|c|c|}
\hline & & \multicolumn{2}{|c|}{2012} & \multicolumn{2}{|c|}{2013} & \multicolumn{2}{|c|}{2014} \\
\hline L.P. & Nazwa wskaźnika & $\begin{array}{l}\text { Gmina } \\
\text { Zgierz }\end{array}$ & $\begin{array}{l}\text { Srednia } \\
\text { dla gmin } \\
\text { wiejskich }\end{array}$ & $\begin{array}{l}\text { Gmina } \\
\text { Zgierz }\end{array}$ & $\begin{array}{l}\text { Srednia } \\
\text { dla gmin } \\
\text { wiejskich } \\
\end{array}$ & $\begin{array}{l}\text { Gmina } \\
\text { Zgierz }\end{array}$ & \begin{tabular}{|l|} 
Srednia \\
dla gmin \\
wiejskich \\
\end{tabular} \\
\hline $\mathbf{Z 1}$ & $\begin{array}{l}\text { Udzial zobowiązań } \\
\text { ogólem w dochodach } \\
\text { ogolem }\end{array}$ & $39,2 \%$ & $28,8 \%$ & $32,0 \%$ & $27,8 \%$ & $23,2 \%$ & $27,7 \%$ \\
\hline $\mathbf{Z 2}$ & $\begin{array}{l}\text { Obciązenie dochodów } \\
\text { ogólem obslugą } \\
\text { zadlużenia }\end{array}$ & $11,9 \%$ & $9,2 \%$ & $9,7 \%$ & $8,9 \%$ & $7,7 \%$ & $5,8 \%$ \\
\hline $\mathbf{Z 3}$ & $\begin{array}{l}\text { Obciążenie dochodów } \\
\text { wlasnych obshugą } \\
\text { zadhizenia }\end{array}$ & $23,5 \%$ & $30,3 \%$ & $18,2 \%$ & $15,0 \%$ & $13,8 \%$ & $16,7 \%$ \\
\hline $\mathrm{Z4}$ & $\begin{array}{l}\text { Udzial zobowiązań } \\
\text { wymagalnych } \\
\text { zobowiązaniach ogóem }\end{array}$ & $0,0 \%$ & $0,7 \%$ & $0,0 \%$ & $0,7 \%$ & $0,0 \%$ & 0,7 \\
\hline
\end{tabular}

Źródło: Opracowanie własne na podstawie danych Ministerstwa Finansów 
Wskaźnik Z1 wskazuje jaką część dochodów ogółem stanowią zobowiązania. W roku 2012 wskaźnik ten był dla gminy Zgierz stosunkowo wysoki i wynosił $39,2 \%$. Widoczna jest jednak tendencja spadkowa. W 2014 r. wskaźnik ten spadł do 23,2 \% i był niższy o 4,5 pkt. proc. od średniej wartości wskaźnika dla innych gmin. Świadczy to o znacznej redukcji zadłużenia przez gminę.

Kolejny wskaźnik Z2 informuje jak jednostka samorządu terytorialnego radzi sobie z obsługą zadłużenia. Według ustawy nie może przekraczać on $15 \%$. Gmina Zgierz osiąga wyższą niż średnio inne gminy wartość wskaźnika. Podobnie jak w przypadku Z1 tak i tutaj wyraźna jest tendencja spadkowa, co oznacza, obsługa długu jest dla jednostki mniejszym obciążeniem.

Również wartość wskaźnika Z3 mówiący o obciążeniu dochodów własnych obsługą zadłużenia ma trend malejący. W roku 2014 relacja ta wyniosła 13,8\% co było wartością mniejszą od średniej dla innych gmin wiejskich. Malejąca wartość wskaźnika świadczy od zmniejszającym się ryzyku niewypłacalności gminy.

Ostatnim wskaźnikiem dla zobowiązań według tytułów dłużnych jest udział zobowiązań wymagalnych w zobowiązaniach ogółem (Z4). Wskaźnik ten dla gminy Zgierz w całym badanym okresie wynosił 0 co świadczy o braku problemów z terminowym regulowaniem płatności.

\section{Podsumowanie}

Analiza wskaźnikowa pozwala na głębsze zbadanie zależności pomiędzy dochodami a wydatkami oraz nadwyżką operacyjną. Dzięki niej możemy poznać przyczynę kształtowania się różnych pozycji budżetowych. Analiza wskaźnikowa dostarcza informacji potrzebnych do podejmowania strategicznych decyzji w jednostce samorządu terytorialnego związanych z wykonywaniem zadań na rzecz ludności lokalnej, zaciąganiem zobowiązań czy rozpoczynaniem nowych inwestycji. 
Gmina Zgierz w badanym okresie wypadła bardzo dobrze. We wszystkich latach wykazywała nadwyżkę budżetową spowodowaną dynamicznym wzrostem dochodów. Gmina nie ma problemów z terminowym regulowaniu płatności, a ryzyko niewypłacalności jest niewielkie. Pomimo, iż na mieszkańca przypada tu więcej wypracowanej nadwyżki operacyjnej to podejmowanych jest mniej inwestycji niż średnio w innych gminach wiejskich

\section{Bibliografia:}

Będzieszak M. Komu potrzebne sq wskaźniki?, Gospodarka i finanse, 2012, dostęp

http://www.wspolnota.org.pl/index.php?id=9\&tx_news_pi1\%5Bcontroller\% 5D=News\&tx_news_pi1\%5Baction\%5D=detail\&tx_news_pi1\%5Bnews\%5D= $25176 \&$ cHash $=596978$ ee684be84f2e05224bcad545b3 z dnia 07.05.2016r.

Jastrzębska M. Finanse jednostek samorzq̨du terytorialnego, Wolters Kluwer Polska, Warszawa, 2012.

Jastrzębska M. Nowy model samorządu terytorialnego. Istota, zadania, autonomia, władze, jednostki organizacyjne, finanse, nadzór., Samorząd terytorialny, 1999, nr 1-2.

Kosek- Wojnar M. Samodzielność jednostek samorządu terytorialnego w sferze wydatków [w:] Zeszyty naukowe nr 4 Wyższej Szkoły Ekonomicznej w Bochni, 2006.

Kosek-Wojnar M. Surówka K., Finanse samorzq̨du terytorialnego, Kraków 2002.

Łukomska- Szarek J. Analiza wskaźnikowa w procesie zarzq̨dzania finansami samorządów [w:] Studaii Materiały. Miscellanea Oeconomicae, Zarządzanie i finanse nr 2/2012, Kielce, 2012.

Łukomska- Szarek J. Wskaźnikowa ocena działalności inwestycyjnej samorzqdów terytorialnych. [w:] Zeszyty Naukowe Uniwersytetu Szczecińskiego „Finanse, Rynki Finansowe, Ubezpieczenia” nr 26, 2010. 
Mioduchowska- Jaroszewicz Edyta, Metody i kierunki oceny kondycji finansowej jednostek samorządu terytorialnego, Zeszyty naukowe Uniwersytetu Szczecińskiego nr 786, Finanse, Rynki Finansowe, Ubezpieczenia nr 64/2, 2013.

Panejko J. Geneza i podstawy samorzq̨du europejskiego, Wilno, 1934.

Raport o stanie gminy Zgierz, Zgierz, 2013.

Strategia rozwoju gminy Zgierz na lata 2015-2020, Zgierz, 2015.

Wyrębek H. Zarządzanie finansami jednostek samorzqdu terytorialnego na przykładzie gminy [w:] Zeszyty Naukowe. Polityki europejskie, zarządzanie i marketing. Nr 4 (53), 2010.

Wskaźniki do oceny sytuacji finansowej jednostek samorzq̨du terytorialnego w latach 2012-2014, Ministerstwo Finansów, Warszawa, 2015. 